\title{
Clinical trials on drug repositioning for COVID-19 treatment
}

\author{
Sandro G. Viveiros Rosa ${ }^{1}$ and Wilson C. Santos ${ }^{1}$
}

Suggested citation Rosa SGV and Santos WC. Clinical trials on drug repositioning for COVID-19 treatment. Rev Panam Salud Publica. 2020;44:e40. https://doi.org/10.26633/RPSP.2020.40

ABSTRACT

The World Health Organization (WHO) was informed on December 2019 about a coronavirus pneumonia outbreak in Wuhan, Hubei province (China). Subsequently, on March 12, 2020, 125,048 cases and 4,614 deaths were reported. Coronavirus is an enveloped RNA virus, from the genus Betacoronavirus, that is distributed in birds, humans, and other mammals. WHO has named the novel coronavirus disease as COVID-19. More than 80 clinical trials have been launched to test coronavirus treatment, including some drug repurposing or repositioning for COVID-19. Hence, we performed a search in March 2020 of the clinicaltrials.gov database. The eligibility criteria for the retrieved studies were: contain a clinicaltrials. gov base identifier number; describe the number of participants and the period for the study; describe the participants' clinical conditions; and utilize interventions with medicines already studied or approved for any other disease in patients infected with the novel coronavirus SARS-CoV-2 (2019-nCoV). It is essential to emphasize that this article only captured trials listed in the clinicaltrials.gov database. We identified 24 clinical trials, involving more than 20 medicines, such as human immunoglobulin, interferons, chloroquine, hydroxychloroquine, arbidol, remdesivir, favipiravir, lopinavir, ritonavir, oseltamivir, methylprednisolone, bevacizumab, and traditional Chinese medicines (TCM). Although drug repurposing has some limitations, repositioning clinical trials may represent an attractive strategy because they facilitate the discovery of new classes of medicines; they have lower costs and take less time to reach the market; and there are existing pharmaceutical supply chains for formulation and distribution.

Keywords Drug repositioning; clinical trials as topic; coronavirus infection; virus diseases; pneumonia, viral; pandemics.

The World Health Organization (WHO) was informed on December 31, 2019, about a pneumonia outbreak in Wuhan, Hubei province (China), a city with 11 million inhabitants. By March 12, 2020, there were 125048 cases and 4614 deaths (nearly $3.7 \%$ of cases) reported for the novel coronavirus (1), named 2019-novel coronavirus (2019-nCoV), and later renamed as severe acute respiratory syndrome coronavirus 2 (SARS-CoV-2) (2). The WHO named this novel coronavirus disease as COVID-19 $(1,2)$, and there have been confirmed cases in 117 countries or territories outside China, including Japan, the United States of America, Italy, Iran, and Brazil (1). Coronavirus is an enveloped RNA virus, from the genus Betacoronavirus, that is distributed in birds, humans, and other mammals $(3,4)$. New evidence indicates a link between SARS-CoV-2 and bat coronavirus (3). Six species of coronavirus are known as infectious in humans, four of which (229E, OC43, NL63, and HKU1) cause common cold symptoms (4). However, some authors have claimed that SARS-CoV-2 is even related to the coronavirus species responsible for the severe acute respiratory syndrome (SARS-CoV) as well as Middle East Respiratory Syndrome (MERS-CoV), which have zoonotic origins linked to severe significant illness with higher mortality $(3,4)$. For example, in July 2003, the WHO reported 8437 SARS-CoV cases, especially in China and Hong Kong, with 813 related deaths (5). Concerning MERS-CoV, from June 2012 to April 2018, 2206 people were infected in 27 countries, 1831 cases in Saudi Arabia, with 787 deaths (6). Unfortunately, there are no vaccines or medicines approved for the novel coronavirus infection

Universidade Federal Fluminense, Rio de Janeiro, Brazil. $\bowtie$ Sandro Guim-

arães Viveiros Rosa, sandrogvr@gmail.com

This is an open access article distributed under the terms of the Creative Commons Attribution-NonCommercial-NoDerivs 3.0 IGO License, which permits use, distribution, and reproduction in any medium, provided the original work is properly cited. No modifications or commercial use of this article are permitted. In any reproduction of this article there should not be any suggestion that PAHO or this article endorse any specific organization or products. The use of the PAHO logo is not permitted. This notice should be preserved along with the article's original URL. 
(7), but more than 80 clinical trials have been launched to test coronavirus treatments, including some drug repurposing or repositioning for COVID-19 (8). Drug repositioning for other neglected diseases is an essential and universal strategy in the development of new drugs due to: a) lower costs and reduced time to reach the market because some clinical trial steps might not be required, especially concerning phases I and II; $b$ ) existing pharmaceutical supply chains are available for formulation and distribution; $c$ ) the possibility of combinations with other drugs in treatments that are more effective than monotherapy; and $d$ ) may facilitate the discovery of new mechanisms of action for old drugs and new classes of medicines $(9,10)$.

On the other hand, this repurposing strategy has some limitations, including patent barriers, the complexity of regulatory pathways, absence of funding opportunities, greater access to data from other industry-sponsored clinical trials, and the heterogeneity of the population for new clinical studies (10). Nevertheless, drug repurposing is still a tool for the discovery of entirely new classes of medicines $(10,11)$. Hence, considering this scenario, we felt that it is of interest to be aware of the drug repositioning in clinical tests for the COVID2019 treatment.

\section{METHODS}

We performed a search on March 12, 2020, at the clinicaltrials. gov database, with the descriptor [coronavirus] in the simple search field "conditions or disease" search, without restrictions on languages, disease conditions, results, or locations. The eligibility criteria for the retrieved studies were: contain a clinicaltrials.gov base identifier number; describe the number of participants and the study period; describe the patient's clinical conditions; and interventions utilize medicines already studied or approved for any other disease in patients with COVID-19. ClinicalTrials.gov is a resource from the US National Library of Medicine, and it contains clinical studies conducted by 209 countries.

\section{RESULTS AND DISCUSSION}

We identified 24 clinical trials (Table 1), in which 19 studies were at clinical phases 2, 3, or 4. The pharmaceutical interventions found for COVID-19 treatment include human immunoglobulin, interferons, chloroquine, hydroxychloroquine, arbidol, remdesivir, oseltamivir, favipiravir, carrimycin, methylprednisolone, bevacizumab, thalidomide, vitamin C, pirfenidone, bromhexine, fingolimod, danoprevir, ritonavir, darunavir, cobicistat, lopinavir, xiyanping, and traditional Chinese medicines (TCM).

Chloroquine and hydroxychloroquine are antimalarial drugs. They have antiviral effects against human immunodeficiency virus (HIV), namely by inhibiting virus entry into host cells. Another antiviral mechanism is related to the post-translation alteration of newly synthesized proteins via glycosylation inhibition (12). Hydroxychloroquine is already being used in clinical trials on acquired immune deficiency syndrome (AIDS) treatment (13). In a recent trial with patients on COVID-19 treatment (14), 100\% of patients treated with hydroxychloroquine in combination with the macrolide antibiotic azithromycin were virologically cured comparing with $57.1 \%$ in patients treated with hydroxychloroquine alone, and
$12.5 \%$ in the control group. Currently, chloroquine and hydroxychloroquine will be tested $(15,16)$ in patients with pneumonia caused by 2019-nCoV and chloroquine as preventative medicine for COVID-19, as shown in Table 1.

Immunoglobulins are useful in several diseases, such as idiopathic thrombocytopenia purpura (ITP), Guillain-Barre Syndrome (GBS), chronic inflammatory demyelinating polyneuropathy (CIDP), Kawasaki disease, and in multiple neurological autoimmune disorders refractory to standard immunosuppressive treatments (17). Broadly neutralizing antibodies can recognize a wide variety of glycoproteins (GPs) in virus surfaces or the protein shell of a non-enveloped virus. However, HIV-1, dengue virus (DENV), influenza viruses, hepatitis C virus $(\mathrm{HCV})$, and Ebola virus (EBOV) can mutate superficial GPs in order to evade the antibody response, an obstacle in the development of new therapies against such infections (18). Trial NCT04261426 (19) is utilizing human immunoglobulin in patients with pneumonia caused by 2019-nCoV (Table 1).

Two clinical studies refer to the use of remdesivir in severe (20) or mild (21) respiratory infections by SARS-CoV-2. Remdesivir is a nucleotide analog inhibitor of the EBOV RNA-polymerase RNA-dependent (RdRp). Dyer et al. 2019 (22) described preliminary findings of a mortality rate of 33\% in 499 patients treated with remdesivir against the EBOV disease in early infection stages. The same authors noted a mortality rate of $75 \%$ (almost 1900 people) of non-treated infected patients during the same epidemic period (22). Wang et al. 2020 (23) presented data showing that remdesivir is effective against the 2019-nCoV in Vero E6 cells $\left(\mathrm{EC}_{90} 1.76 \mu \mathrm{M}\right)$. The suggested mechanism for remdesivir involves the host cells' post-entry stage (23).

Arbidol, also known as umifenovir, is approved in Russia and China for the treatment of influenza virus infections; it does not have significant adverse effects and is patented for SARS treatment (24). As shown in Table 1, four clinical trials will be conducted for COVID-19 treatment: one with arbidol in comparison with the basic treatment (25), and the other three studies comparing effects with oseltamivir $(26,27)$, lopinavirritonavir (27), and carrimycin (28). The arbidol anti-viral mechanism against influenza $\mathrm{A}$ and $\mathrm{B}$ involves viral fusion inhibition with the targeted membrane, which blocks virus entry into the cell (24). Oseltamivir is another drug approved for influenza A and B treatment; it inhibits the viral neuraminidase and, consequently, blocks the release of viral particles from host cells, reducing the spread in the respiratory tract (29). Additionally, the use of oseltamivir was already reported during the COVID-19 epidemic in China, either with or without antibiotics and corticosteroids (30). Oseltamivir is also used in a clinical trial with multiple combinations with chloroquine and favipiravir (31), a nucleoside analog that is well-known as a broad-spectrum antiviral drug; it has shown (23) an $\mathrm{EC}_{50}$ of $61.88 \mu \mathrm{M}$ against SARS-CoV-2 and low toxicity (CC50 >400 $\mu \mathrm{M})$.

The lopinavir-ritonavir combination is approved for AIDS treatment in several countries. Both drugs are HIV protease inhibitors, but ritonavir is also a cytochrome P450 and GP inhibitor, a fact that endorses the lopinavir pharmacokinetic and pharmacodynamic activities against HIV (32). Such a combination, plus $\beta-1 b$ interferon, is in phase 2 for the MERS treatment (33). Several trials involve lopinavir-ritonavir treatment in comparison with the use of other drugs for COVID-19: 
TABLE 1. Clinical trials identified at Clinicaltrials.gov related to drug repositioning for COVID-19 treatment

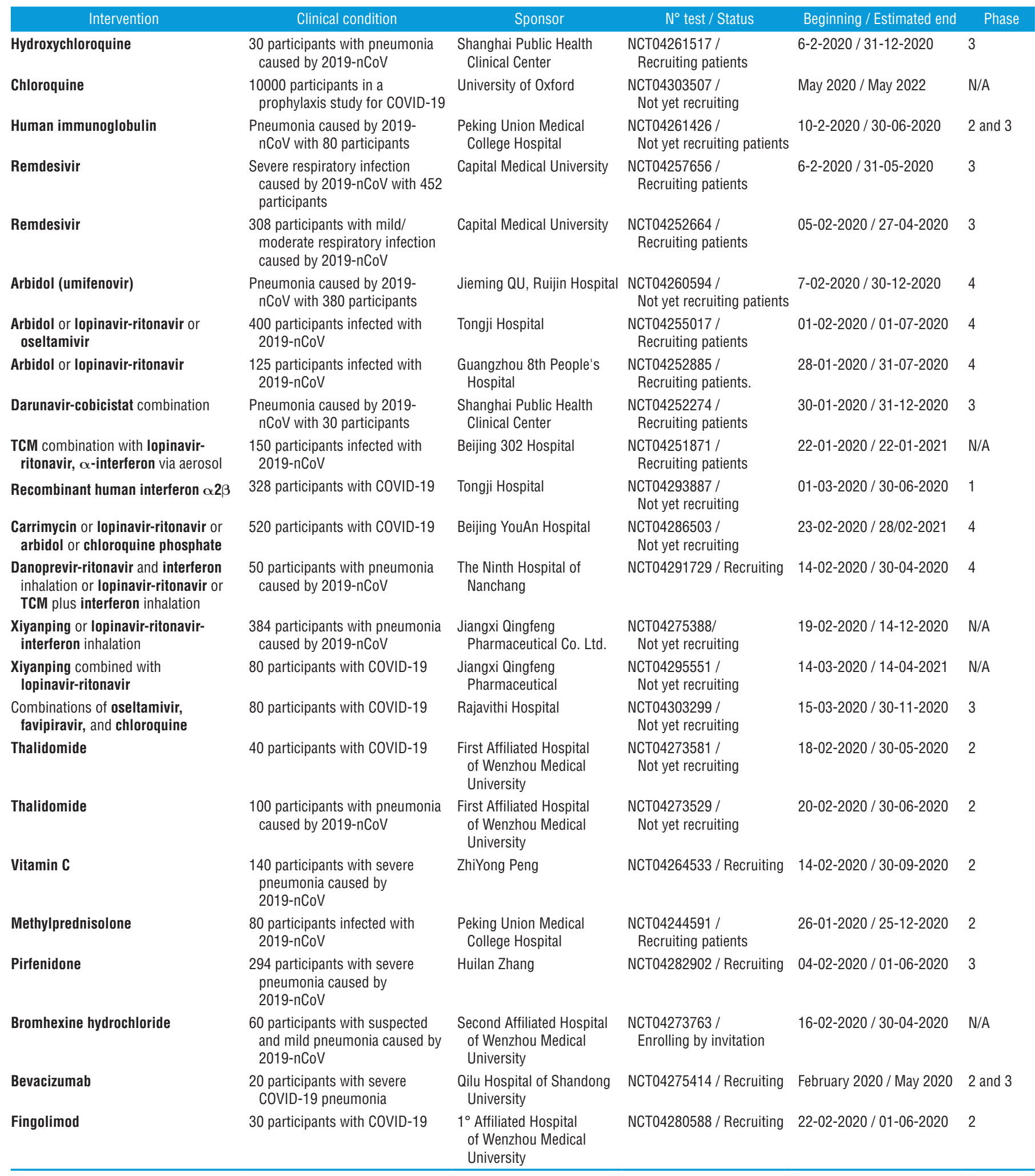

COVID-19, coronavirus disease 2019; 2019-nCoV, novel coronavirus 2019; TCM, traditional Chinese medicine 
arbidol $(26,27)$, carrimycin $(28)$, TCM $(34,35)$, xiyanping $(36,37)$, danoprevir-ritonavir (38) and interferon inhalation $(34,38)$. Nevertheless, one previous article argued that in a clinical trial with 199 patients with laboratory-confirmed SARS-CoV-2 infection, the lopinavir-ritonavir combination was not associated with clinical improvement comparing with standard care procedures (39).

Carrimycin is a macrolide antibiotic with effects against some gram-positive bacteria and in vitro effects on Mycobacterium tuberculosis (40).

Danoprevir is an HCV NS3 protease inhibitor approved in China for the treatment of non-cirrhotic genotype $1 \mathrm{~b}$ chronic hepatitis $C$, in combination with ritonavir, peginterferon- $\alpha$, and ribavirin (41).

Traditional Chinese medicine (TCM) uses phytotherapeutic formulations such as teas, pills, powders or tinctures, and cultural components that originated 5000 years ago in Chinese medicine (42). TCMs were already used for SARS-CoV infection in 2002 as coadjuvant therapy with the enhancement of patients' symptoms, increased oxyhemoglobin arterial saturation; they proved useful in the early stages of this infection (42).

Interferons (IFNs) are proteins that bind to cellular surfaces' receptors and initiate JAK-STAT signaling cascades, with transcriptional regulation of genes controlled by interferons and effects against some viruses like hepatitis B virus and HCV (43).

Xiyanping is a TCM preparation with andrographolide as a principal component; it has significant antibacterial and antiviral effects (44).

Darunavir, in combination with cobicistat, will be used in trial number NCT04252274 (45) in patients with COVID-19 pneumonia. The United States Food and Drug Administration (FDA) currently approves such a combination in AIDS treatment. Darunavir is another HIV protease inhibitor, and cobicistat, like ritonavir, is a booster for enhancing the pharmacokinetics and pharmacodynamics of darunavir by cytochrome P450 (CYP3A) inhibition $(46,47)$.

Recombinant human interferon $\alpha 2 \beta$ is described to have inhibitory effects on MERS-CoV and SARS-CoV (48), and the purpose of the clinical trials found for this paper is to evaluate the efficacy and safety of recombinant human interferon $\alpha 2 \beta$ in treating patients with new coronavirus infection (49).

Thalidomide will be used in two trials against COVID-19 $(49,50)$. Thalidomide has an anti-inflammatory action due to its ability to speed up the degradation of messenger RNA in blood cells and thus reduce tumor necrosis factor- $\alpha$ (TNF $\alpha)$. Furthermore, thalidomide can increase the secretion of interleukins, such as IL-12, and activate natural killer cells (51).

The corticosteroid methylprednisolone will be tested against COVID-19 (52). Long et al. 2016 (53) reported that corticosteroid therapy (methylprednisolone, dexamethasone, and hydrocortisone) is beneficial in treating SARS-CoV patients; it significantly prolongs the survival time of clinical cases. Nevertheless, other authors described the use of corticosteroids in the early stages of SARS infection with increasing values of viral load (54). Furthermore, studies with corticosteroids in the adjuvant therapy of MERS-CoV infection were unable to prove efficacy because all patients died (55). Methylprednisolone has already been used in COVID-19 patients in combination with antibiotics, oseltamivir, and oxygen therapy (56).
Finally, vitamin C (ascorbic acid), pirfenidone, bevacizumab, fingolimod, and bromhexine hydrochloride are going to be tested on COVID-19 (57-61). Vitamin C has antioxidant activity and may reduce oxidative stress and inflammation $(57,62)$, effects that improve vasopressor synthesis, enhance immune cell function, improve endovascular function, and provide epigenetic immunologic modifications. Clinical trials have demonstrated promising data on mortality improvement in sepsis, but more extensive studies are necessary to validate these conclusions (63). Pirfenidone has been used in the treatment of idiopathic pulmonary fibrosis diseases due to anti-inflammatory and anti-oxidant effects, namely by inhibiting IL-1 $\beta$ and IL-4 (58). Trial NCT04282902 claimed (58) that anti-inflammatory effects may be helpful in SARS-CoV-2 infection. Bevacizumab is a humanized monoclonal antibody that targets vascular endothelial growth factor (VEGF) $(59,63)$, and it may reduce the levels of VEGF caused by hypoxia, severe inflammation, and upregulation of the infected respiratory tract epithelium, all of which might suppress the edema in patients with COVID-19 (63). Fingolimod is a sphingosine-1-phosphate receptor regulator (FTY720) with an effective immunology modulator that is useful in multiple sclerosis (60). According to some pathological findings of pulmonary edema and hyaline membrane formation, the use of immune modulators, together with ventilator support, should be considered for severe patients to prevent the development of acute respiratory distress syndrome (ARDS). Study NCT04280588 aims to determine the efficacy of fingolimod for COVID-19 (60). Bromhexine is a transmembrane protease serine inhibitor; such a protease is responsible for the activation of S-glycoprotein of SARS-CoV and MERS-CoV for viral entry through the plasma membrane $(61,64)$. One study $(60)$ will evaluate the efficacy of bromhexine combined with standard treatment/standard treatment in patients with COVID-19.

In conclusion, the WHO declared an epidemic of pneumonia caused by the SARS-CoV-2 in 2020. In this review, we found 24 clinical trials that have already started with the repositioning of more than 20 medicines for COVID-19 treatment, such as human immunoglobulin, interferons, chloroquine, hydroxychloroquine, arbidol, remdesivir, favipiravir, oseltamivir, thalidomide, methylprednisolone, bevacizumab, and TCM. The Hydroxychloroquine-azithromycin combination was the first drug repurposed with excellent results in clinical trials against SARS-CoV-2, but further, more extended studies, with a higher number of patients, are needed to confirm these results. Besides its limitations, repositioning clinical trials are still an attractive strategy: they may facilitate the discovery of new classes of medicines; they may reduce the costs and time to reach the market; there is an existing pharmaceutical supply chain for formulation and distribution; and there is the possibility of combinations with other drugs in treatments that are more effective than monotherapy. Most of the studies found in this article are scheduled to end in 2020, and we hope these repositioning trials may help to find solutions for COVID-19 treatment by this year.

\section{Conflicts of interest. None declared.}

Disclaimer. Authors hold sole responsibility for the views expressed in the manuscript, which may not necessarily reflect the opinion or policy of the RPSP/PAJPH and/or PAHO. 


\section{REFERENCES}

1. World Health Organization (WHO). Novel Coronavirus (2019$\mathrm{nCoV}$ ) Situation Report - 52. Data as reported by 12 March 2020. Available from https://www.who.int/docs/default-source/ coronaviruse /20200312-sitrep-52-covid-19.pdf?sfvrsn=e2bfc9c0_2 Accessed on 12 March 2020.

2. Perrella A, Carannante N, Berretta M, Rinaldi M, Maturo N, Rinaldi L. Editorial - Novel Coronavirus 2019 (Sars-CoV2): a global emergency that needs new approaches? Eur Rev Med Pharmaco. 2020; 24:2162-2164.

3. del Rio C, Malani PN. 2019 Novel Coronavirus-Important Information for Clinicians. JAMA. Published online February 05, 2020. DOI:10.1001/jama.2020.1490

4. Zhu N, Zhang D, Wang W, Li X, Yang B, Song J, et al. A Novel Coronavirus from Patients with Pneumonia in China, 2019. N Engl J Med. 2020;1-7.

5. Zhong NS, Zheng BJ, Li YM, Poon LLM, Xie ZH, Chan KH, et al. Epidemiology and cause of severe acute respiratory syndrome (SARS) in Guangdong, People's Republic of China, in February 2003. Lancet. 2003;362(9393):1353-8.

6. Nassar MS, Bakhrebah MA, Meo SA, Alsuabeyl MS, Zaher WA. Middle East Respiratory Syndrome Coronavirus (MERS-CoV) infection: epidemiology, pathogenesis and clinical characteristics. Eur Rev Med Pharmaco. 2018;22(15):4956-61.

7. Li G, De Clercq E. Therapeutic options for the 2019 novel coronavirus (2019-nCoV). Nat Rev Drug Discov. 2020;1-8. Available from: http:/ / www.nature.com/articles/d41573-020-00016-0

8. Maxmen A. Slew of trials launch to test coronavirus treatments in China. Nature. 2020; 78: 37-348

9. Mercorelli B, Palù G, Loregian A. Drug Repurposing for Viral Infectious Diseases: How Far Are We? Trends Microbiol. 2018;26(10):865-876. Available from: https://doi.org/10.1016/j. tim.2018.04.004

10. Pushpakom S, Iorio F, Eyers PA, Escott KJ, Hopper S, Wells A, et al. Drug repurposing: progress, challenges and recommendations. Nat Rev Drug Discov. 2018; 18(1): 41-58. Available from: DOI:10.1038/ nrd.2018.168

11. Neuberger A, Oraiopoulos N, Drakeman DL. Renovation as innovation: is repurposing the future of drug discovery research? Drug Discov Today. 2019;24(1):1-3. Available from: https://doi. org/10.1016/j.drudis.2018.06.012

12. Rolain JM, Colson P, Raoult D. Recycling of chloroquine and its hydroxyl analogue to face bacterial, fungal and viral infections in the 21st century. Int J Antimicrob Agents. 2007;30(4):297-308.

13. ClinicalTrials.gov [Internet]. Bethesda (MD): National Library of Medicine (US). 2020 Feb 18 - Identifier NCT01067417, Evaluation of the Efficacy of Hydroxychloroquine in Decreasing Immune activation in asymptomatic HIV-infected patients (HCQ01). Available from https://clinicaltrials.gov/ct2/show/NCT01067417.

14. Gautret P, Lagier JC, Parola P, Hoang VT, Meddeb L, Mailhe, et al. Hydroxychloroquine and azithromycin as a treatment of COVID-19: results of an open-label non-randomized clinical trial. Int J Antimicrob Agents - In Press 17 March 2020. DOI : 10.1016/j. ijantimicag.2020.105949

15. Bethesda (MD): National Library of Medicine (US). 2020 Mar 12 Identifier NCT04303507, Chloroquine Prevention of Coronavirus Disease (COVID-19) in the Healthcare Setting (COPCOV). Available from: https://clinicaltrials.gov/ct2/show /NCT04303507?term= NCT04303507\&draw $=2 \&$ rank $=1$

16. ClinicalTrials.gov [Internet]. Bethesda (MD): National Library of Medicine (US). 2020 Mar 12 - Identifier NCT04261517. Efficacy and Safety of Hydroxychloroquine for Treatment of Pneumonia Caused by $2019-\mathrm{nCoV}$ (HC-nCoV). Available from: https://clinicaltrials. gov/ct2/show/NCT04261517.

17. Cherin P, Marie I, Michallet M, Pelus E, Dantal J, Crave JC, et al. Management of adverse events in the treatment of patients with immunoglobulin therapy: A review of evidence. Autoimmun Rev. 2016;15(1):71-81. Available from: http://dx.doi.org/10.1016/j. autrev.2015.09.002

18. Varadarajan R, Srinivasan S, Maity S, Ghosh M. Broadly neutralizing antibodies for therapy of viral infections. Antib Technol J. $2016 ; 1$.
19. ClinicalTrials.gov [Internet]. Bethesda (MD): National Library of Medicine (US). 2020 Mar 12 - Identifier NCT04261426, The Efficacy of Intravenous Immunoglobulin Therapy for Severe 2019-nCoV infected pneumonia. Available from: https://clinicaltrials.gov/ct2/ show /NCT04261426

20. ClinicalTrials.gov [Internet]. Bethesda (MD): National Library of Medicine (US). 2020 Mar 12 - Identifier NCT04257656, Severe2019nCoV Remdesivir RCT. Available from: https://clinicaltrials.gov/ ct2/show/NCT04257656. Accessed on 18 February 2020

21. NCT04252664. Mild / Moderate 2019-nCoV Remdesivir RCT. Available from: https://clinicaltrials.gov/ct2/show/NCT04252664. Accessed on 18 February 2020

22. Dyer O. Two Ebola treatments halve deaths in trial in DRC outbreak. BMJ. 2019;366(August):15140. Available from: http://dx.doi. org/doi:10.1136/bmj.15140

23. Wang M, Cao R, Zhang L, Yang X, Liu J, Xu M, et al. Remdesivir and chloroquine effectively inhibit the recently emerged novel coronavirus (2019-nCoV) in vitro. Cell Res. 2020;(January):2019-21. Available from: http://www.ncbi.nlm.nih.gov/pubmed/32020029

24. Blaising J, Polyak SJ, Pécheur EI. Arbidol as a broad-spectrum antiviral: An update. Antiviral Res. 2014;107(1):84-94. Available from: http://dx.doi.org/10.1016/j.antiviral.2014.04.006

25. ClinicalTrials.gov [Internet]. Bethesda (MD): National Library of Medicine (US). 2020 Mar 12 - Identifier NCT04260594, Clinical Study of Arbidol Hydrochloride Tablets in the Treatment of Pneumonia Caused by Novel Coronavirus. Available from: https:// clinicaltrials.gov/ct2/show/NCT04260594.

26. ClinicalTrials.gov [Internet]. Bethesda (MD): National Library of Medicine (US). 2020 Mar 12 - Identifier NCT04255017, A prospective, randomized controlled clinical study of antiviral therapy in the 2019-nCoV pneumonia. Available from: https://www.clinicaltrials. gov/ct2/show/NCT04255017.

27. ClinicalTrials.gov [Internet]. Bethesda (MD): National Library of Medicine (US). 2020 Mar 12 - Identifier NCT04252885, The efficacy of lopinavir plus ritonavir and arbidol against novel coronavirus infection (ELACOI). Available from: https:/ / clinicaltrials.gov/ct2/ show/study/NCT04252885.

28. ClinicalTrials.gov [Internet]. Bethesda (MD): National Library of Medicine (US). 2020 Mar 12 - Identifier NCT04286503, The clinical study of carrimycin on treatment patients with Covid19. Available from: https://clinicaltrials.gov/ct2/show/ NCT04286503?term=NCT04286503\&draw $=2 \&$ rank $=1$

29. Uyeki TM. Oseltamivir Treatment of Influenza in Children. Clin Infect Dis. 2018;66(10):1501-3.

30. Wang D, Hu B, Hu C, Zhu F, Liu X, Zhang J, et al. Clinical Characteristics of 138 Hospitalized Patients With 2019 Novel Coronavirus-Infected Pneumonia in Wuhan, China. JAMA. 2020;Feb7:1-9. Available from: http://www.ncbi.nlm.nih.gov/pubmed/32031570

31. ClinicalTrials.gov [Internet]. Bethesda (MD): National Library of Medicine (US). 2020 Mar 12 - Identifier NCT04303299, Various combination of Protease Inhibitors, Oseltamivir, Favipiravir, and Chloroquin for Treatment of COVID-19: A Randomized Control Trial (THDMS-COVID19)

32. Okubo K, Isono M, Asano T, Sato A. Lopinavir-ritonavir combination induces endoplasmic reticulum stress and kills urological cancer cells. Anticancer Res. 2019;39(11):5891-901.

33. Arabi YM, Alothman A, Balkhy HH, Al-Dawood A, AlJohani S, Al Harbi S, et al. Treatment of Middle East Respiratory Syndrome with a combination of lopinavir-ritonavir and interferon- $\beta 1 \mathrm{~b}$ (MIRACLE trial): Study protocol for a randomized controlled trial. Trials. 2018;19(1):1-13.

34. ClinicalTrials.gov [Internet]. Bethesda (MD): National Library of Medicine (US). 2020 Mar 12 - Identifier NCT04251871, Treatment and prevention of traditional Chinese medicines (TCMs) on 2019$\mathrm{nCoV}$ infection. Available from https://clinicaltrials.gov/ct2/ show $/$ NCT04251871?term $=$ NCT04251871 \&draw $=2 \&$ rank $=1$

35. ClinicalTrials.gov [Internet]. Bethesda (MD): National Library of Medicine (US). 2020 Mar 12 - Identifier NCT04251871, Treatment and Prevention of Traditional Chinese Medicines (TCMs) on2019$\mathrm{nCoV}$ Infection. Available from: https://clinicaltrials.gov/ct2/ show /NCT04251871 
36. ClinicalTrials.gov [Internet]. Bethesda (MD): National Library of Medicine (US). 2020 Mar 12 - Identifier NCT04275388, Xiyanping injection for the treatment of new coronavirus infected pneumonia. Available from: https://clinicaltrials.gov/ct2/show/ NCT04275388? term $=$ NCT04275388\&draw $=2 \&$ rank $=1$

37. ClinicalTrials.gov [Internet]. Bethesda (MD): National Library of Medicine (US). 2020 Mar 12 - Identifier NCT04295551, Multicenter clinical study on the efficacy and safety of Xiyanping injection in the treatment of the new coronavirus infection pneumonia (general and severe). Available from: https://clinicaltrials.gov/ct2/show/ NCT04295551?term $=$ NCT04295551\&draw $=2 \&$ rank $=1$

38. ClinicalTrials.gov [Internet]. Bethesda (MD): National Library of Medicine (US). 2020 Mar 12 - Identifier NCT04291729, Evaluation of Ganovo (danoprevir) combined with ritonavir in the treatment of the novel coronavirus infection. Available from: https:/ / clinicaltrials.gov/ct2/show / NCT04291729?term = NCT04291729\&draw $=2 \&$ rank $=1$

39. Cao B et al. A Trial of Lopinavir-Ritonavir in Adults Hospitalized with Severe Covid-19. 1-13 (2020). DOI:10.1056/NEJMoa2001282

40. Wang Y, Jiang Y, Zhao C, He W. Use of carrimycin in Mycobacterium tuberculosis infection resistance. China. US20190001160. 2019

41. Markham A, Keam SJ. Danoprevir: First Global Approval. Drugs. 2018;78:1271-1276 Available from: https:/ /doi.org/10.1007/s40265018-0960-0

42. Luo Y, Wang CZ, Hesse-Fong J, Lin JG, Yuan CS. Application of Chinese Medicine in Acute and Critical Medical Conditions. Am J Chin Med. 2019;47(6):1223-35.

43. Schneider WM, Chevillotte MD, Rice CM. Interferon-Stimulated Genes: A Complex Web of Host Defenses NIH Public Access. 2015;32:513-45. DOI:10.1146/annurev-immunol-032713-120231.

44. Tang T. Application of Xiyanping in treatment of infantile rotavirus diarrhea. J Hainan Med Univ. 2016;22(13):113-5.

45. ClinicalTrials.gov [Internet]. Bethesda (MD): National Library of Medicine (US). 2020 Mar 12 - Identifier NCT04252274. Efficacy and Safety of Darunavir and Cobicistat for Treatment of Pneumonia Caused by 2019-nCoV (DACO-nCoV). Available from: https:/ / clinicaltrials.gov/ct2/show/NCT04252274

46. Santos JR, Curran A, Navarro-Mercade J, Ampuero MF, Pelaez P, Pérez-Alvarez N, et al. Simplification of Antiretroviral Treatment from Darunavir/Ritonavir Monotherapy to Darunavir/Cobicistat Monotherapy: Effectiveness and Safety in Routine Clinical Practice. AIDS Res Hum Retroviruses. 2019;35(6):513-8.

47. Mathias AA, German P, Murray BP, Wei L, Jain A, West S, Warren D, Hui J, Kearney BP. Pharmacokinetics and Pharmacodynamics of cobicistat GS-9350: A Novel Pharmacokinetic Enhancer Without Anti-HIV Activity. Clin Pharmacol Ther. 2010;87(3):322-329. DOI:10.1038/clpt.2009.228

48. ClinicalTrials.gov [Internet]. Bethesda (MD): National Library of Medicine (US). 2020 Mar 12 - Identifier NCT04293887, Efficacy and safety of IFN- $\alpha 2 \beta$ in the treatment of novel coronavirus patients. Available from: https://clinicaltrials.gov/ct2/show/ NCT04293887?term $=$ NCT04293887\&draw=2\&rank=1

49. ClinicalTrials.gov [Internet]. Bethesda (MD): National Library of Medicine (US). 2020 Mar 12 - Identifier NCT04273581, The efficacy and safety of thalidomide combined with low-dose hormones in the treatment of severe Covid-19. Available from: https://clinicaltrials.gov $/$ ct $2 /$ show $/$ NCT04273581?term $=$ NCT04273581\&draw $=2 \&$ rank=1

50. ClinicalTrials.gov [Internet]. Bethesda (MD): National Library of Medicine (US). 2020 Mar 12 - Identifier NCT04273529, The efficacy and safety of thalidomide in the adjuvant treatment of moderate new coronavirus (Covid-19) pneumonia. Available from: https:// clinicaltrials.gov / ct2/show / NCT04273529?term $=$ NCT04273529\& draw $=2 \&$ rank $=1$

51. Newfield C. New Medical Indications for Thalidomide and its Derivatives New Medical Indications for Thalidomide and its
Derivatives. The Science Journal of the Lander College of Arts and Sciences. 2018;12(1).

52. ClinicalTrials.gov [Internet]. Bethesda (MD): National Library of Medicine (US). 2020 Mar 12 - Identifier NCT04244591. Glucocorticoid Therapy for Novel Coronavirus Critically Ill Patients With Severe Acute Respiratory Failure (Steroids-SARI). Available from: https://clinicaltrials.gov/ct2/show/NCT04244591.

53. Long $\mathrm{Y}, \mathrm{Xu} \mathrm{Y}$, Wang B, Zhang L, Jia D, Xue F, et al. Clinical recommendations from an observational study on MERS: Glucocorticoids was benefit in treating SARS patients. Int J Clin Exp Med. 2016;9(5):8865-73.

54. Lee N, Allen Chan KC, Hui DS, Ng EKO, Wu A, Chiu RWK, et al. Effects of early corticosteroid treatment on plasma SARS-associated Coronavirus RNA concentrations in adult patients. J Clin Virol. 2004;31(4):304-9.

55. Al-Tawfiq JA, Memish ZA. Update on therapeutic options for Middle East Respiratory Syndrome Coronavirus (MERS-CoV). Expert Rev Anti Infect Ther. 2017;15(3):269-75. Available from: http://dx. doi.org/10.1080/14787210.2017.1271712

56. Huang C, Wang Y, Li X, Ren L, Zhao J, Hu Y, et al. Clinical features of patients infected with 2019 novel coronavirus in Wuhan, China. Lancet. 2020;497-506.

57. ClinicalTrials.gov [Internet]. Bethesda (MD): National Library of Medicine (US). 2020 Mar 12 - Identifier NCT04264533, Vitamina $\mathrm{C}$ infusion for the treatment of severe $2019-\mathrm{nCoV}$ infected pneumonia. Available from: https://clinicaltrials.gov/ct2/show/ NCT04264533?term $=$ NCT04264533\&draw $=2 \&$ rank $=1$

58. ClinicalTrials.gov [Internet]. Bethesda (MD): National Library of Medicine (US). 2020 Mar 12 - Identifier NCT04282902, A study to evaluate the efficacy and safety of Pirfenidone with novel coronavirus infection. Available from: https://clinicaltrials.gov/ct2/show/ NCT04282902?term $=$ NCT04282902\&draw $=2 \&$ rank=1

59. ClinicalTrials.gov [Internet]. Bethesda (MD): National Library of Medicine (US). 2020 Mar 12 - Identifier NCT04275414, Bevacizumab in severe or critical patients with Covid-19 pneumonia (BEST-CP). Available from: https://clinicaltrials.gov/ct2/show/ NCT04275414?term $=$ NCT04275414\&draw $=2 \&$ rank $=1$

60. ClinicalTrials.gov [Internet]. Bethesda (MD): National Library of Medicine (US). 2020 Mar 12 - Identifier NCT04280588, Fingolimod in COVID-19. Available from: https://clinicaltrials.gov/ct2/show / NCT04280588? term $=$ NCT04280588\&draw $=2 \&$ rank $=1$

61. ClinicalTrials.gov [Internet]. Bethesda (MD): National Library of Medicine (US). 2020 Mar 12 - Identifier NCT04273763, Evaluating the efficacy and safety of bromhexine hydrochloride tablets combined with standard treatment/standard treatment in patients with suspected and mild coronavirus pneumonia (COVID-19). Available from: https://clinicaltrials.gov/ct2/show/ NCT04273763?term $=$ NCT04273763\&draw $=2 \&$ rank $=1$

62. Kashiouris MG, L'heureux M, Cable CA, Fisher BJ, Leichtle SW Fowler AA. The emerging role of vitamin $\mathrm{C}$ as a treatment for sepsis. Nutrients. 2020;12(2):1-16.

63. Wang Y, Fei D, Vanderlaan M, Song A. Biological activity of bevacizumab, a humanized anti-VEGF antibody in vitro. Angiogenesis. 2004;7(4):335-45.

64. Li CC, Wang XJ, Wang HCR. Repurposing host-based therapeutics to control coronavirus and influenza virus. Drug Discov Today. 2019;24(3):726-36. Available from: https://doi.org/10.1016/j. drudis.2019.01.018

Manuscript received on 19 February 2020. Revised version accepted for publication on 20 March 2020 


\section{Ensayos clínicos de reposicionamiento de medicamentos para el tratamiento de la COVID-19}

RESUMEN En diciembre de 2019 fue informado a la Organización Mundial de la Salud (OMS) un brote de neumonía por coronavirus en Wuhan, provincia de Hubei, China. Al 12 de marzo de 2020, se habían notificado 125048 casos y 4614 muertes. El coronavirus es un virus ARN envuelto del género Betacoronavirus distribuido en aves, seres humanos y otros mamíferos. La OMS ha denominado a la nueva enfermedad por coronavirus COVID19. Se han puesto en marcha más de 80 ensayos clínicos para evaluar un tratamiento para el coronavirus, que incluyen algunos ensayos de reposicionamiento de medicamentos para la COVID-19. En marzo de 2020 se llevó a cabo una búsqueda de los ensayos clínicos registrados en la base de datos clinicaltrials.gov. Los criterios de elegibilidad para los estudios recuperados fueron tener un número de identificación de la base de datos clinicaltrials.gov; describir el número de participantes y el período del estudio; describir las condiciones clínicas de los participantes; y emplear intervenciones con medicamentos ya estudiados o aprobados para cualquier otra enfermedad en pacientes infectados con el nuevo coronavirus SARS-CoV-2 (2019-nCoV). Es esencial destacar que este artículo solo recoge los ensayos que figuran en la base de datos clinicaltrials. gov. Se identificaron 24 ensayos clínicos relacionados con más de 20 medicamentos, como inmunoglobulina humana, interferones, cloroquina, hidroxicloroquina, arbidol, remdesivir, favipiravir, lopinavir, ritonavir, oseltamivir, metilprednisolona, bevacizumab y medicina tradicional china. Aunque el reposicionamiento de medicamentos tiene algunas limitaciones, el reposicionamiento de los ensayos clínicos puede representar una estrategia atractiva porque facilita el descubrimiento de nuevas clases de medicamentos; estos tienen costos más bajos y tardan menos en llegar al mercado; y existen cadenas de suministro farmacéutico que apoyan la formulación y la distribución.

Palabras clave Reposicionamiento de medicamentos; ensayos clínicos como asunto; infecciones por coronavirus; virosis; neumonía viral; pandemias.

\section{Ensaios clínicos de reposicionamento de medicamentos para o tratamento do COVID-19}

RESUMO A Organização Mundial da Saúde (OMS) foi informada, em dezembro de 2019, sobre um surto de pneumonia por coronavírus em Wuhan, província de Hubei (China). Posteriormente, em 12 de março de 2020, 125 048 casos e 4614 mortes haviam sido registrados. O coronavírus é um vírus RNA envelopado do gênero Betacoronavírus, distribuído em aves e em humanos e outros mamíferos. A OMS designou a nova doença por coronavírus como COVID-19. Mais de 80 ensaios clínicos foram iniciados para testar tratamentos para o coronavírus, incluindo alguns de reposicionamento de medicamentos para o COVID-19. Assim, em março de 2020 realizou-se uma busca na base de dados clinicaltrials.gov. Os critérios de elegibilidade para os estudos recuperados foram: conter o número identificador da base de dados clinicaltrials.gov; descrever o número de participantes e o período do estudo; descrever as condições clínicas dos participantes; e utilizar intervenções para tratamento de doentes infectados com o novo coronavírus SARS-CoV-2 (2019-nCoV) com medicamentos já estudados ou aprovados para qualquer outra doença. É essencial salientar que este artigo apenas capturou ensaios listados na base de dados clinicaltrials.gov. Foram identificados 24 ensaios clínicos envolvendo mais de 20 medicamentos, tais como imunoglobulina humana, interferons, cloroquina, hidroxicloroquina, arbidol, remdesivir, favipiravir, lopinavir, ritonavir, oseltamivir, metilprednisolona, bevacizumabe e medicamentos chineses tradicionais. Embora o reposicionamento de medicamentos tenha algumas limitações, os ensaios clínicos de reposicionamento podem representar uma estratégia atraente, porque facilitam a descoberta de novas classes de medicamentos, têm custos mais baixos, levam menos tempo para chegar ao mercado e se beneficiam de cadeias de fornecimento farmacêutico já existentes para formulação e distribuição.

Palavras-chave Reposicionamento de medicamentos; ensaios clínicos como assunto; infecções por coronavirus; viroses; pneumonia viral; pandemias. 